\title{
Studi komparasi model grup investigation dan problem based learning dalam meningkatkan critical thinking skill siswa SMA
}

\author{
Adi Widya Krisnawati, Yuswanti Ariani Wirahayu*, Yusuf Suharto \\ Universitas Negeri Malang, Jl. Semarang No. 5 Malang, Jawa Timur, Indonesia \\ *Penulis korespondensi, yuswanti.ariani.fis@um.ac.id
}

Paper received: 03-01-2021; revised: 15-01-2021; accepted: 30-01-2021

\begin{abstract}
Abstrak
Kemampuan berpikir kritis dapat dicapai dengan model yang tepat, beberapa diantaranya menggunakan model Group Investigation dan Problem Based Learning. Berdasarkan kelebihan kedua model maka penulis meneliti perbedaan hasil Group Investigation dengan Problem Based Learning terhadap kemampuan berpikir kritis dan mencari tahu manakah yang lebih tinggi. Rancangan penelitian menggunakan metode eksperimen semu, pelaksanaanya dengan nonequivalent control group design. Subjek penelitian adalah siswa kelas X MA Nurul Ulum Malang. Kelas eksperimen 2 (X IIS 3) perlakuan Problem Based Learning dan kelas eksperimen 2 (X IIS 4) perlakuan Group Investigation. Hasil analisis data diketahui bahwa rata-rata gain score di kelas eksperimen 1 adalah 34,60, sedangkan kelas eksperimen 2 adalah 27,05. Analisis menggunakan uji Independent t-test diperoleh nilai signifikansi sebesar 0,045 < 0,050 maka H0 ditolak, membuktikan bahwa ada perbedaan kedua model pembelajaran terhadap kemampuan berpikir kritis.
\end{abstract}

Kata kunci: group investigation; problem based learning; kemampuan berpikir kritis.

\section{Pendahuluan}

Pembelajaran dengan kemampuan berpikir kritis perlu diterapkan karena banyak manfaat yang diperoleh siswa di dalam maupun di luar sekolah. Pertama, siswa tidak sekedar hafalan dan hitungan melainkan penyelidikan untuk memperoleh prinsip atau konsep. Jadi diharapkan siswa mengalami sendiri proses mencari tahu kebenaran tentang pengetahuan tersebut. Kedua, sangat penting di abad 21 dimana siswa harus merespon perubahan dengan cepat, kreatif dan efektif sehingga memerlukan keterampilan intelektual yang fleksibel, artinya dengan memiliki kemampuan berpikir kritis siswa mampu menganalisis informasi dan mengintegrasikan berbagai sumber pengetahuan untuk memecahkan masalah atau pencarian solusi. Ketiga, membantu siswa untuk menyeleksi, menilai dan memutuskan hal-hal yang diyakini dan dilakukan. Keempat, mengevaluasi ide baru, memilih yang terbaik dan memodifikasi apabila perlu.

Salah satu model pembelajaran inovatif yang mampu membangun sebuah argumen dan mendukung proses pembelajaran untuk meningkatkan kemampuan berpikir kritis adalah model Group Investigation dan Problem Based Learning. Perbandingan pengaruh model pembelajaran Group Investigation dengan model Problem Based Learning dipilih sebagai penelitian eksperimen didasarkan pada beberapa alasan. Alasan tersebut antara lain: (1) sesuai dengan kebutuhan kurikulum 2013, (2) kedua model melatih siswa untuk mengasah kemampuan berpikir kritis, (3) sesuai apabila diterapkan pada pembelajaran geografi, (4) alasan perbandingan kedua model karena memiliki tahapan pembelajaran yang hampir sama sebagi model kooperatif. 
Persamaan tahapan antara model Group Investigation dan Problem Based Learning. Pada tahapan ketiga melakukan investigasi atau penyelidikan secara berkelompok. Tahap penyelidikan kedua model siswa sama-sama mengumpulkan informasi, mengidentifikasi masalah, menganalisis data, membuat kesimpulan terkait dengan permasalahn yang diselidiki. Tahapan keempat dan kelima dari Group Investigation dan keempat dari Problem Based Learning. Meskipun berbeda namun memiliki kesamaan kegiatan yaitu membuat laporan akhir atau hasil karya dan melakukan presentasi atau menyajikan leporan kerja kelompok. Tahapan keenam pada Group Investigation dan tahapan kelima Problem Based Learning melakukan evaluasi tentang pembelajaran yang sudah dilaksanakan.

Perbedaan Group Investigation dengan Problem Based Learning terletak pada tahapan satu dan dua masing-masing model. Pemberian perlakuan awal yaitu mengidentifikasi topik dan membentuk kelompok. Topik yang ditemui dalam kehidupan sehari-hari belum tentu sebuah permasalahn yang membutuhkan solusi. Sedangkan Problem Based Learning mengorientasi siswa terhadap masalah, siswa dituntut untuk mencari alternatif solusinya jadi cangkupannya sedikit lebih sempit dibanding Group Investigation. Tahapan dua, pada Group Investigation adalah perencanaan pelaksanaan investigasi. Siswa merencanakan kegiatan penyelidikan meliputi merumuskan masalah utama dari topik, menentukan tujuan, dan merencanakan proses investigasi, sedangkan Problem Based Learning mengorganisasi siswa untuk belajar. Siswa mengorganisasi tugas dengan kelompok untuk mengidentifikasi permasalahn pada artikel meliputi identifikasi faktor penyebab permasalahn, dampak dan pemecahan masalah.

Berdasarkan uraian kedua model untuk meningkatkan kemampuan berpikir kritis siswa, perlu dilakukan penelitian mengenai penggunaan model Group Investigation dan Problem Based Learning dalam pembelajaran Geografi dengan judul "Perbandingan Pengaruh Model Group Investigation dan Model Problem Based Learning terhadap Kemampuan Berpikir Kritis Siswa Kelas X MA Nurul Ulum Malang".

\section{Metode}

Penelitian yang digunakan termasuk metode penelitian eksperimen dengan betuk quasi experimental design. Pendekatan penelitian adalah pendekatan kuantitatif karena penelitian yang analisisnya lebih fokus pada data numerikal yang diolah menggunakan metode statistika. Pelaksanaan eksperimen menggunakan nonequivalent control group design karena kelompok eksperimen tidak dipilih secara random dengan dua kelompok subyek penelitian yang memiliki kemampuan sama (homogen).

Tabel 1. Rancangan Penelitian

\begin{tabular}{llll}
\hline Kelompok & Pre test & Treatment & Post test \\
\hline Eksperimen 1 $\left(\mathrm{E}_{1}\right)$ & $\mathrm{O}_{1}$ & $\mathrm{X}_{1}$ & $\mathrm{O}_{1}$ \\
Eksperimen 2 $\left(\mathrm{E}_{2}\right)$ & $\mathrm{O}_{1}$ & $\mathrm{X}_{2}$ & $\mathrm{O}_{1}$ \\
\hline
\end{tabular}

Sumber: Sugiyono (2015:116)

Keterangan

E1 : kelas eksperimen 1

E2 : kelas eksperimen 2

01 : pretest kelas eksperimen 1 dan posttest kelas eksperimen 2

01 : posttest kelas eksperimen 1 dan posttest kelas ekperimen 2

X1 : treatment menggunakan model Group Investigation 
Subjek dalam penelitian ini adalah siswa kelas X IIS MA Nurul Ulum Malang semester genap tahun 2018/2019 yang terdiri dari dua kelas putri yaitu X IIS 3 mendapat perlakuan Problem Based Learnin dan kelas X IIS 4 berjumlah sama yaitu 22 siswa perlakuan Group Investigation. Teknik pemilihan subjek dalam penelitia ini menggunakan purposive sampling karena teknik pengambilan sampel berdasarkan pada karakteristik tertentu yang dianggap mempunyai sangkut pautnya dengan karakteristik populasi. Kedua kelas memiliki kemampuan akademik hampir sama berdasarkan rata-rata hasil PAS dan kedua kelas diajar oleh guru yang sama. Hasil rata-rata penilaian akhir semester (PAS) kelas X IIS 3 adalah 80,09 dan X IIS 4 adalah 79,63.

Instrumen dalam penelitian ini menggunakan soal tes. Tes untuk prates dan pascates berupa soal subjektif. Soal terdiri dari 5 butir soal subjektif yang dibuat sama untuk kelas eksperimen 1 dan kelas eksperimen 2. Penyusunan soal tes disesuaikan dengan indikator kemampuan berpikir kritis, yakni setiap item soal mewakili tiap-tiap indikator kemampuan berpikir kritis. Sebelum instrumen digunakan untuk pengambilan data, terlebih dahulu dilakukan uji instrumen yaitu validitas dan reliabilitas.

Analisis data menggunakan model uji-t sampel tidak berpasangan. Teknik analisis uji-t dilakukan dengan menggunakan program SPSS 16.0 for windows dengan taraf signifikansi 0,05. Uji prasyarat terdiri dari uji normalita dan uji homogenitas. Setelah dilakukan uji prasyarat, selajutnya uji hipotesis sebagai langkah atau prosedur untuk menguji hipotesis penelitian yang diujikan diterima atau ditolak.

\section{Hasil dan Pembahasan}

Pemberian prates dilaksanakan pada kelas eksperimen 1 dan eksperimen 2. Data ini bertujuan untuk mengetahui kemampuan siswa sebelum dilakukan perlakuan untuk mengukur kemampuan berpikir kritis. Distribusi nilai prates untuk mengetahui frekuensi (banyaknya siswa) dan persentase. Terdapat lima kualifikasi yaitu sangat baik, baik, cukup, kurang baik, dan sangat kurang. Selain itu terdapat rentangan nilai yang sudah disusun, semakin banyak siswa mencapai nilai tinggi maka kualifikasi semakin sangat baik. Berdasarkan hasil prates diperoleh data distribusi frekuensi sebagai berikut.

Tabel 2. Distribusi Prates Kelas Eksperimen 1 dan Kelas Eksperimen 2

\begin{tabular}{llllll}
\hline \multirow{2}{*}{ Kualifikasi } & \multirow{2}{*}{ Nilai } & \multicolumn{2}{l}{ Kelas Eksperimen 1 } & \multicolumn{2}{c}{ Kelas Eksperimen 2 } \\
\cline { 3 - 6 } & & Frekuensi & Persentase & Frekuensi & Persentase \\
\hline Sangat Baik & $91-100$ & 0 & 0 & 0 & 0 \\
Baik & $75-90$ & 0 & 0 & 0 & 0 \\
Cukup & $60-74$ & 6 & 27 & 3 & 14 \\
Kurang Baik & $40-59$ & 8 & 36 & 13 & 59 \\
Sangat Kurang & $<40$ & 8 & 36 & 6 & 27 \\
\hline Jumlah Siswa & & 22 & 100 & 22 & 100 \\
\hline
\end{tabular}

Berdasarkan tabel tersebut nilai prates pada kelas eksperimen 1 tergolong homogen, tidak ada siswa yang mencapai kualifikasi "sangat baik" dan "baik", sedangakan 6 siswa yang mempunyai nilai dalam kriteria cukup. Kemudian lebih banyak siswa yang mendapatkan nilai "kurang baik" dan "sangat kurang" dengan jumlah yang sama yaitu 8 siswa. diperoleh data 
distribusi kemampuan berpikir kritis berikut. Hasil prates kelas eksperimen 2 diketahui dari jumlah 22 siswa tidak ada yang mencapai kualifikasi "sangat baik" dan "baik". Kualifikasi "cukup" dengan rentangan nilai 60-74 berjumlah 3 siswa yang mencapainya. 13 siswa masuk dalam kualifikasi kurang baik, apabila dibandingkan dengan kelas eksperimen kualifikasi kurang baik kelas eksperimen 2 lebih banyak. Terakhir 6 siswa dengan kualifikasi "sangat kurang".

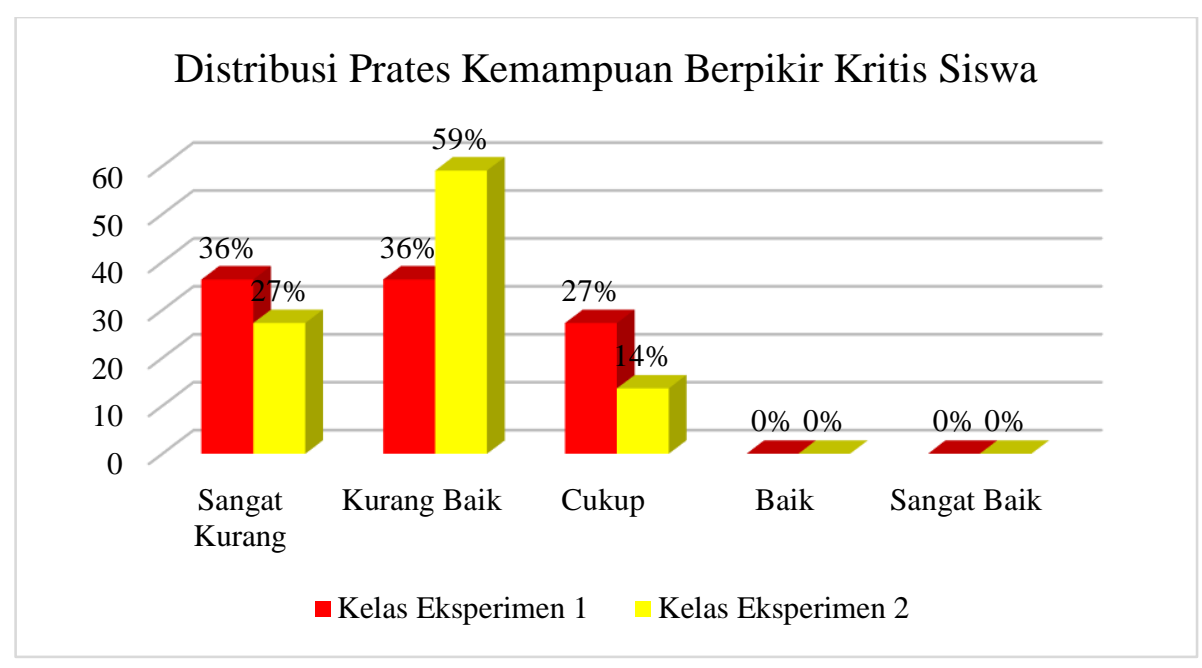

Gambar 1. Diagram Distribusi Nilai Prates Kelas Eksperimen 1 dan Kelas Eksperimen 2

Diagram di atas menunjukkan sebaran nilai prates kelas eksperimen 1 tidak ada siswa yang mencapai kualifikasi "sangat baik" dan "baik" artinya peresentase $0 \%$, kualifikasi "cukup" dengan persentase 27\%. Dapat disimpulkan bahwa nilai prates kelas eksperimen 1 masih tergolong rendah dengan persentase sama $36 \%$ pada kualifikasi "kurang baik" dan "sangat kurang". Hal tersebut membuktikan siswa belum menguasai beberapa materi hidrosfer dan dampaknya terhadap kehidupan. Distribusi prates kelas eksperimen 2 persebaran datanya menunjukkan ada tiga rentangan nilai yaitu "cukup" dengan persentase $14 \%$, "kurang baik" mendominasi dibandingkan rentangan nilai lainnya yaitu 59\%, sedangkan sangat kurang mencapai 27\%, kualifikasi "sangat baik" dan "baik" tidak ada satupun siswa yang menempuhnya, apabila dibandingkan dengan hasil rata-rata kelas eksperimen 1, pencapaian prates kelas eksperimen 2 lebih baik.

Pascates dilaksanakan setelah siswa menapatkan perlakuan, pada kelas eksperimen 1 dan eksperimen 2. Data ini bertujuan untuk mengetahui kemampuan akhir siswa setelah dilakukan perlakuan untuk mengukur kemampuan berpikir kritis. Berdasarkan hasil pascates kelas eksperimen diperoleh data distribusi frekuensi berikut.

Tabel 3. Distribusi Pascates Eksperimen 1 dan Kelas Eksperimen 2

\begin{tabular}{llllll}
\hline \multirow{2}{*}{ Kualifikasi } & & \multicolumn{2}{l}{ Kelas Eksperimen 1 } & \multicolumn{2}{l}{ Kelas Eksperimen 2 } \\
\cline { 3 - 6 } & Nilai & Frekuensi & Persentase & Frekuensi & Persentase \\
\hline Sangat Baik & $91-100$ & 6 & 27 & 3 & 14 \\
Baik & $75-90$ & 14 & 64 & 12 & 55 \\
Cukup & $60-74$ & 2 & 9 & 7 & 32 \\
Kurang Baik & $40-59$ & 0 & 0 & 0 & 0 \\
Sangat Kurang & $<40$ & 0 & 0 & 0 & 0 \\
\hline Jumlah Siswa & & 22 & 100 & 22 & 100 \\
\hline
\end{tabular}


Distribusi nilai pascates kelas eksperimen 1 menunjukkan 6 siswa mencapai nilai 91100 dengan kualifikasi "sangat baik". Lebih dari setengah jumlah siswa tergolong "baik" yaitu 14 sampel, sedangkan 2 siswa lainnya tergolong dalam kualifikasi "cukup". Kualifikasi "kurang baik" dan "sangat kurang" tidak ada frekuensi jumlah siswa. Distribusi niali pascates kelas eksperimen 2 berbeda dengan sebaran nilai prates. Frekuensi kemampuan berpikir kritis menunjukkan 3 siswa yang memiliki kualifikasi "sangat baik", 12 siswa mencapai kualifikasi "baik" dengan rentangan nilai 75-90, kualifikasi "kurang baik" sebanyak 7 siswa dan tidak ada siswa yang memiliki kualifikasi "kurang baik" dan "sangat kurang". Berdasarkan tabel distribusi pascates agar data dapat dilihat lebih jelas dan mudah dipahami maka dapat dipaparka sebagai berikut.

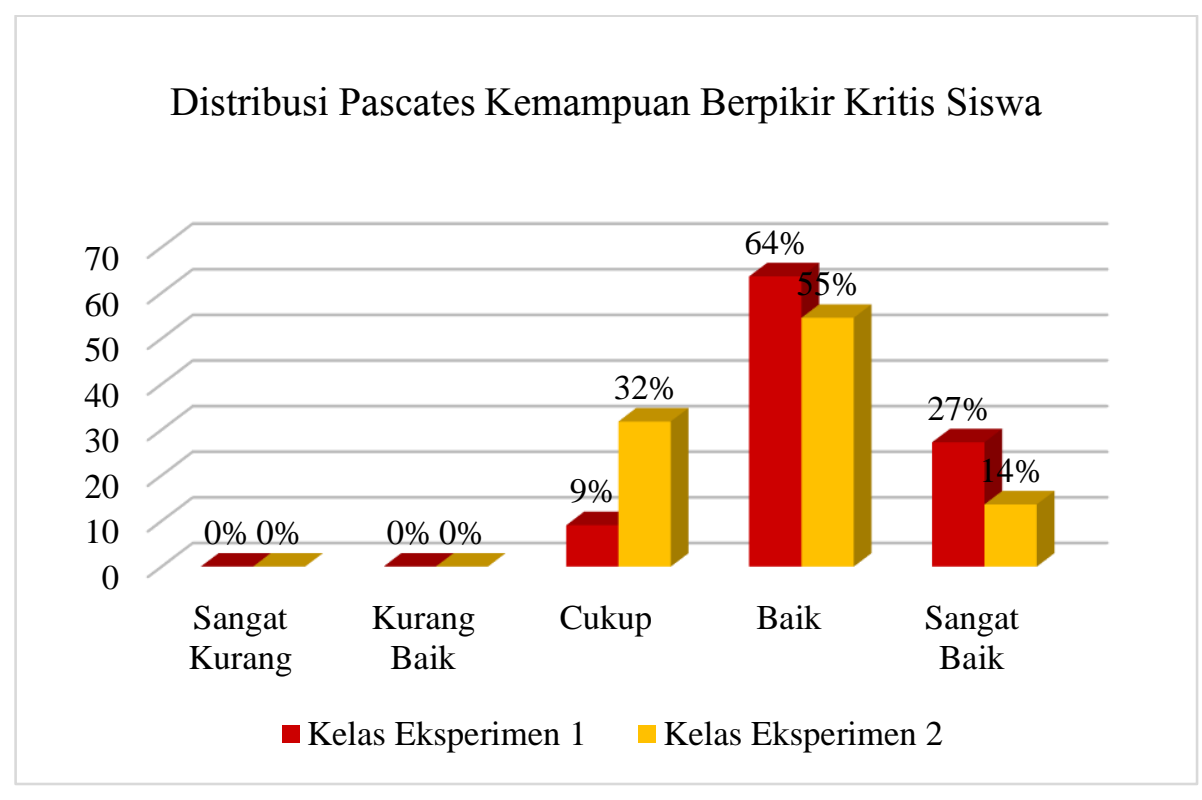

\section{Diagram 2. Distribusi Nilai Pascates Kelas Eksperimen 1 dan Kelas Eksperimen 2}

Bedasarkan diagram di atas persentase kelas eksperimen 1 sebesar $27 \%$ tergolong kualifikasi "sangat baik". Persentase teritinggi pada kualifikasi "baik" mencapai 64\%, sedangkan cukup 9\%, menunjukkan sebagian besar siswa kelas eksperimen 1 mengalami peningkatan berpikir kritis sangat signifikan. Hal tersebut dibuktikan kualifikasi "kurang baik" dan "sangat kurang" tidak ada frekuensi jumlah siswa. Distribusi pascates kelas eksperimen 2 menunjukkan hasil "sangat baik" persentase 14\%, sebagian besar didominasi kualifikasi "baik" dengan persentase $55 \%$, dan sisanya $32 \%$ mendapat nilai cukup, sedangkan yang mendapat nilai kurang baik dan sangat kurang tidak ada $0 \%$. Uji coba instrumen soal prates dan pascates dilaksanakan di kelas XI IIS 3. Jumlah siswa yang mengerjakan soal pada uji instrumen yaitu 27 sampel jawaban.

Tabel 4. Kategori Skor Total Uji Validitas

\begin{tabular}{llll}
\hline No Soal & rhitung & Koefisien Korelasi & Klasifikasi \\
\hline 1 & 0,779 & $0,600-0,799$ & Valid \\
2 & 0,620 & $0,600-0,799$ & Valid \\
3 & 0,813 & $0,800-1,000$ & Sangat Valid \\
4 & 0,728 & $0,600-0,799$ & Valid \\
5 & 0,786 & $0,600-0,799$ & Valid \\
\hline
\end{tabular}

Sumber: Purwanto (2005) 
Berdasarkan tabel di atas menurut kategori skor total uji coba diketahui semua butir soal valid. Soal nomor satu, dua, empat dan lima diketahui rhitung masuk dalam kategori "Valid" dengan koefisien korelasi 0,600 - 0,799, sedangkan soal nomor 5 diketahui rhitung masuk dalam kategori koefisien korelasi “Sangat Valid” dengan nilai antara 0,800 - 1,000.

Tabel 5. Hasil Uji Reliabilitas

\begin{tabular}{ll}
\hline Cronbach's Alpha & N of Items \\
\hline .791 & 5 \\
\hline
\end{tabular}

Tingkat reliabilitas setiap item dengan membandingkan $r_{\text {hitung }}$ dengan $r_{\text {tabel, }}, r_{\text {hitung }}$ untuk setiap butir soal dapat dilihat pada kolom cronbach's alpha if item deleted yaitu 22 sampel jadi $r_{\text {hitung }} 0,4044$, disimpulkan 0,791 >0,4044 maka tes tersebut reliabel.

Tabel 6. Hasil Uji Normalitas

\begin{tabular}{lll}
\hline Kelas & Signifikansi & Kesimpulan \\
\hline Eksperimen 1 & 0,837 & Normal \\
Eksperimen 2 & 0,525 & Normal \\
\hline
\end{tabular}

Berdasarkan hasil uji normalitas menunjukkan gainscore kemampuan berpikir kritis memiliki signifikansi data terdistribusi secara normal. Hal tersebut dibuktikan dengan kelas eksperimen 1 memiliki signifikansi 0,837 >0,05, sedangkan kelas eksperimen 2 memiliki signifikansi 0,525 >0,05.

Tabel 7. Hasil Uji Homogenitas

\begin{tabular}{llll}
\hline Levene Statistic & df1 & df2 & Sig. \\
\hline .142 & 1 & 42 & .708 \\
\hline
\end{tabular}

Uji Levene menunjukkan bahwa rhitung 0,142 dengan nilai signifikansi 0,708 >0,05, maka hasil gainscore tes kemampuan berpikir kritis kelas eksperimen 1 dan kelas eksperimen 2 memiliki keragaman yang homogen.

Tabel 8. Hasil Uji Hipotesis

\begin{tabular}{llllll}
\hline & & $\mathrm{F}$ & $\mathrm{Sig}$. & $\mathrm{t}$ & Sig. (2-tailed) \\
\hline \multirow{2}{*}{ Gainscore } & Equal variances assumed & .142 & .708 & 2.062 & .045 \\
& Equal variances not assumed & & & 2.062 & .045 \\
\hline
\end{tabular}

Berdasarkan hasil uji hipotesis menunjukkan bahwa adanya perbedaan pengaruh model Group Investigation dan Problem Based Learning. Pernyataan tersebut dibuktikan bahwa nilai sig. (2-tailed) sebesar 0,045. Nilai 0,045 <0,050, maka H0 ditolak berarti ada perbedaan kemampuan berpikir kritis antara kelas yang menggunaka model Group Investigation dan Problem Based Learning.

Melalui penelitian eksperimen ini, peneliti menemukan bahwa ada perbedaan pengaruh model pembelajaran Group Investigation dan Problem Based Learning terhadap kemampuan 
berpikir kritis. Hal ini didasarkan pada hasil kemampuan berpikir kritis pada kelas eksperimen 1 yang lebih tinggi dibandingkan dengan kelas eksperimen 2. Pada kelas eksperimen 1 sebagian besar siswa memperoleh nilai relatif lebih tinggi dengan katagori cukup, baik dan sangat baik, sedangkan kelas eksperimen 2 memperoleh nilai kategori cukup, baik dan sangat baik lebih rendah. Penerapan model Group Investigation dan Problem Based Learning menunjukkan bahwa terdapat perbedaan pengaruh terhadap kemampuan berpikir kritis siswa. Hasil ini dipengaruhi oleh beberapa faktor antara lain: (1) tahapan model Group Investigation dan Problem Based Learning sesuai dengan sintaks indikator kemampuan berpikir kritis, (2) perbedaan perlakuan antara kedua model terletak pada tahap pelaksanaan pembelajaran yang tidak sama dalam mempengaruhi kemampuan berpikir kriti, selanjutnya akan dibahas sebagai berikut.

Tahap pertama pada kelas eksperimen 1 X IIS 4 mendapatkan perlakuan Group Investigation adalah pemilihan topik dan kelas eksperimen 2 X IIS 3 perlakuan Problem Based Learning yaitu mengorientasi siswa terhadap masalah. Kedua model mengarah pada indikator berpikir kritis yaitu merumuskan masalah karena siswa akan membuat pertanyaan yang memberi arah untuk memperoleh jawaban berdasarkan topik dan permasalahan yang dipilih. Hal tersebut sesuai dengan pendapat Rahmawati (2014) salah satu strategi spesifik untuk meningkatkan berpikir kritis adalah menentukan atau memformulasikan rumusan masalah serta siswa dapat menemukan alternatif masalah. Pada kegiatan ini perbedaan perlakuan kelas eksperimen 1 dan kelas eksperimen 2 .

Tahap kedua perlakuan kedua model menunjang indikator berpikir kritis siswa yaitu memberikan argumen. Hal tersebut dapat dilihat ketika proses diskusi berlangsung, siswa bekerjasama melakukan tugas, memberikan sumbangan pemikiran, dan membuat keputusan bersama. Keterkaitan antara tahap pembelajaran ini dengan indikator berpikir kritis membuat argumen teletak pada kegiatan pengumpulan referensi pendukung topik dan permasalahan. Setiap anggota kelompok dituntut untuk mencari dan memahami konsep-konsep dasar DAS, melalui proses pencarian konsep pada fase inilah kemampuan membuat argumen secara tidak langsung akan tercapai, karena setiap anggota kelompok harus membaca dan memahami terlebih dahulu konsep-konsep dasar DAS agar mampu merancang proses penyelidikan dan merumuskan masalah-masalah sesuai topik dan permaalahan yang dipilih.

Tahap ketiga melakukan investigasi dan penyelidikan kelompok sama dengan melakukan deduksi dan induksi bagian dari indikator berpikir kritis. Sebelum melakukan kegiatan investigasi siswa mengkonstruksi pengetahuan berdasarkan dugaan sementara kemudian membuktikan data dengan fakta hasil penyelidikan. Selanjutnya melakukan induksi diaplikasikan dari kegiatan siswa setelah melaksanakan penyelidikan kemudian membuat kesimpulan sesuai fakta. Pada tahap ini, menuntut siswa untuk terlibat langsung dalam proses pengumpulan data dan informasi yang dibutuhkan sesuai dengan tujuan investigasi kelompok. Keterbatasaan perizinan sebagian besar siswa yang merupakan santri menjadi kekurangan pada tahap ini. Perbedaan tahapan ini menunjukan perbedaan kemampuan setiap siswa. Peran aktif siswa dalam kegiatan pembelajaran dapat meningkatkan kemampuan berpikir kritis sebab mereka secara langsung mendapat pengalaman belajar. Pada fase penyelidikan ini, guru tidak bisa mengontrol secara menyeluruh setiap anggota kelompok karena terbatasnya kemampuan guru dalam mengawasi siswa. 
Tahap keempat kedua model mengarah pada indikator berpikir kritis yaitu melakukan evaluasi. Hal ini disebabkan karena siswa membuat pertimbangan berdasarkan hasil data dan fakta diperlukan. Di tahap ini setiap anggota kelompok saling bertukar informasi dan bekerjasama dalam menganalisis data yang telah diperoleh dari hasil temuan investigasi. Tahap ini mendorong siswa untuk dapat memilih dan memilah data yang didapatkan, karena tidak semua data yang diperoleh dapat digunakan dalam penyusunan laporan dan mengembangkan hasil karya. Setelah melalui proses pemilihan, data tersebut kemudian disusun dalam sebuah laporan agar dapat menjawab rumusan masalah yang telah ditetapkan sebelumnya.

Tahap kelima pada kedua model mampu menunjukkan kemampuan berpikir kritis karena ada beberapa siswa yang antusias saat presentasi, memberikan pertanyaan, menyampaikan tanggapan, namun sebaliknya juga banyak siswa pasif yang kurang memahami materi bahkan kegiatan investigasi dan isi dari laporan dan hasil karya. Penilaian presentasi dapat lihat dari cara berkomunikasi, penyampaian materi, keberanian mengungkapkan pendapat, wawasan dalam bertanya dan menjawab pertanyaan, dan tentu saja kepercayaan diri yang baik.

Tahap keenam pada kedua model merujuk indikator berpikir kritis yaitu melakukan evaluasi, memutuskan dan melaksanakan. Secara keseluruhan pada tahap akhir kedua model memiliki persamaan yaitu guru dan siswa bersama-sama melakukan evaluasi keseluruahan pembelajaran. Siswa membuat hasil pertimbangan berdasarkan fakta. Siswa diberikan kesempatan untuk mengutarakan kesulitan selama proses pembelajaran, meberikan kritik dan saran dan terakhir menyimpulkan materi tentang DAS dan dampaknya terhadap kehidupan. Keunggulan model pembelajaran Group Investigation yang mempengaruhi kemampuan berpikir kritis siswa adalah karena dalam tahapan-tahapan pembelajaran Group Investigation terdapat adanya proses kognitif yang saling mempengaruhi (Oktaviana, 2013).

Tahapan model Group Investigation dan Problem Based Learning secara umum dapat mempengaruhi berpikir kritis siswa, namun tahapan yang paling berpengaruh terhadap kemampuan berpikir kritis adalah tahap investigasi siswa secara kelompok pada perlakuan Group Investigation siswa mengumpulkan informasi melalui kegiatan observasi dan wawancara, sedangkan model Problem Based Learning adalah membimbing penyelidikan kelompok melakukan kajian pustaka di perpustakaan dengan berbagai sumber belajar berupa buku, artikel dan melalui sumber internet. Ketika siswa melaksanakan investigasi dapat membiarkan siswa aktif mencari data yang dibutuhkan sesuai dengan tujuan penyelidikan.

Hasil penelitian yang telah dilakukan menujukkan kemampuan berpikir kritis yang berbeda antara model Group Investigation dan Problem Based Learning. Perbedaan hasil tersebut dikarenakan beberapa faktor. Group Investigation memiliki karakteristik utama sebagai model yang berfokus melaksanakan kegiatan investigasi dilapangan. Selain itu, model ini memberikan kesempatan yang seluas-luasnya kepada siswa untuk terlibat secara langsung dan aktif dalam proses awal hingga akhir pembelajaran. Peryataan tersebut didukung oleh pendapat Arends (2008) bahwa siswa belajar sebaiknya langsung terlibat dengan objek nyata yang ada dalam kehidupan supaya dapat meningkatkan kemampuan berpikir kritis. Pada tahap identifikasi topik yang ditemui dalam kehidupan sehari-hari berkaitan dengan DAS yang belum tentu sebuah permasalahan yang membutuhkan solusi. Siswa berusaha mencari data sendiri 
dengan kegiatan investigasi, menentukan tujuan investigasi, menentukan lokasi dan waktu investigasi hingga analisis dan mempresentasikan hasil laporan diskusi.

Perbedaan model Problem Based Learning memiliki karakterisik utama sebagai model pembelajaran yang berfokus permasalahan yang akan mereka pecahkan dan mencari alternatif solusinya. Masalah bersifat kontekstual untuk memicu ketertarikan dalam mencari solusi dari permasalahan. Keterbatasaan perizinan sebagian besar siswa yang merupakan santri menjadi kekurangan pada tahap ini, oleh sebab itu masalah dihadirkan di dalam kelas berupa artikel yang terfokus seperti kerusakan DAS di wilayah Kota Malang. Informasi mengenai permasalahan seperti lokasi, waktu, wilayah, hingga hubungan sebab akibat diperlukan sebagai bahan pertimbangan dalam penyusunan solusi. Sehingga diperlukan kemampuan berpikir kritis untuk menyelesaikan masalah

\section{Simpulan}

Berdasarkan rumusan masalah dan hasil penelitian, maka disimpulkan bahwa "ada perbedaan kemampuan berpikir kritis siswa dengan menggunakan model Group Investigation dan Problem Based Learning pada siswa kelas X IIS MA Nurul Ulum Malang tahun ajaran 2018/2019". Model pembelajaran Group Investigation lebih tinggi dalam meningkatkan kemampuan berpikir kritis dari pada model Problem Based Learning.

\section{Daftar Rujukan}

Arends, Richard. (2008). Learning to Teaching. Journal of Human Geography, Vol. 1 No. 2 Hal 36-48.

Hosnan, M. (2014). Pendekatan saintifik dan kontekstual dalam pembelajaran abad 21: Kunci sukses implementasi kurikulum 2013.

Kagan, Spencer and Kagan, Miguel. (2009). Kagan Cooperative Learning. San Clemente: Kagan Publishing.

Oktaviana, Melina; Dwiyono Hari Utomo; J.P. Buranda. (2013). Perbandingan Model Pembelajaran Group Investigation (GI) dan Problem Based Learning (PBL) terhadap Kemampuan Berpikir Kritis Siswa Kelas XI SMA Negeri 4 Kediri. Jurnal Pendidikan Geografi UM, Vol. 2, No. 2. Dari (http://karyailmiah.um.ac.id/index.php/Geografi/article/view/28430).

Purwanto, Edy. (2005). Evaluasi Proses dan Hasil dalam Pembelajaran (Aplikasi dalam Bidang Studi Geografi). Malang: Universitas Negeri 1 Malang.

Rahmawati, D., dan H. Sutarto. (2014). Implementasi Group Investigation dengan Scientific Approach Berbasis Portofolio terhadap Kemampuan Berpikir Kritis Matematis. Unnes Journal of Mathematics Education (UJME), Vol. 3 No. 3.

Slavin, Robert E. (2010). Cooperative Learning: teori, riset dan praktik. Diterjemahkan Narulita. Bandung: Nusa Media.

Sugiyono. (2014). Metode Penelitian Pendidikan. Bandung: Alfabeta.

Sumarmi. (2012). Model-model Pembelajaran Geografi. Malang: Aditya Media Publishing. 